\title{
Association between genetic polymorphisms of long non-coding RNA PRNCR1 and prostate cancer risk in a sample of the Iranian population
}

\author{
HEDIEH SATTARIFARD ${ }^{1,2}$, MOHAMMAD HASHEMI ${ }^{1,2}$, SHEKOOFEH HASSANZAREI ${ }^{2}$, \\ BEHZAD NAROUIE $^{3}$ and GHOLAMREZA BAHARI ${ }^{2}$
}

${ }^{1}$ Cellular and Molecular Research Center and ${ }^{2}$ Department of Clinical Biochemistry, School of Medicine, Zahedan University of Medical Sciences, Zahedan 98167-43181; ${ }^{3}$ Urology and Nephrology Research Center, Department of Urology, Shahid Labbafinejad Medical Center, Shahid Beheshti University of Medical Sciences, Tehran 198396-3113, Iran

Received August 23,2017; Accepted October 18, 2017

DOI: $10.3892 / \operatorname{mco} .2017 .1462$

\begin{abstract}
The aim of the present study was to determine whether there is an association between the long non-coding RNA (lncRNA) prostate cancer-associated non-coding RNA 1 (PRNCR1) polymorphisms and prostate cancer (PCa) risk in a sample of the Iranian population. This case-control study was performed on 178 patients with $\mathrm{PCa}$ and 180 subjects with benign prostatic hyperplasia (BPH). Genotyping assay was performed by polymerase chain reaction-restriction fragment length polymorphism. The findings indicated that the GG genotype of the rs13252298 $\mathrm{A}>\mathrm{G}$ variant significantly increased the risk of $\mathrm{PCa}$ (odds ratio $=3.49,95 \%$ confidence interval: $1.79-6.81, \mathrm{P}=0.0001$ ) compared with $\mathrm{AA}+\mathrm{AG}$. As regards the rs1456315 G>A polymorphism, the AG genotype and $G$ allele significantly increased the risk of $\mathrm{PCa}$. As regards the rs7841060 $\mathrm{T}>\mathrm{G}$ variant, the findings demonstrated that this TG genotype and the $\mathrm{G}$ allele significantly increased the risk of PCa. The rs7007694 $\mathrm{T}>\mathrm{C}$ variant was not found to be associated with the risk of PCa. Haplotype analysis indicated that GTGA and GTGG significantly increased the risk of PCa compared with rs1456315A/rs7007694T/rs7841060T/rs13252298G (ATTG). The PRNCRl variants were not found to be significantly associated with the clinicopathological characteristics of $\mathrm{PCa}$ patients. In conclusion, our findings support an association between PRNCR 1 variants and the risk of PCa in a sample of the Iranian population.
\end{abstract}

Correspondence to: Professor Mohammad Hashemi, Department of Clinical Biochemistry, School of Medicine, Zahedan University of Medical Sciences, Khalij Fars Boulevard, Zahedan 98167-43181, Iran

E-mail:mhd.hashemi@gmail.com; hashemim@zaums.ac.ir

Key words: prostate cancer-associated non-coding RNA 1, polymorphism, prostate cancer, long non-coding RNA

\section{Introduction}

Prostate cancer $(\mathrm{PCa})$ is one of the most frequently diagnosed cancers in men and the sixth leading cause of cancer-related mortality among men worldwide (1). The prevalence of PCa differs significantly among populations, indicating that the host's genetic background may play an important role in susceptibility to PCa (2). Single-nucleotide polymorphisms (SNPs) are the most common type of genetic variations in human genome, and they have been found to be associated with the risk of PCa (3-6). Genome tiling arrays have indicated that $1 \%$ of the human genome is composed of protein-coding sequences and $\sim 4-9 \%$ of the sequences of the human genome are transcribed to non-coding RNAs (ncRNAs) (7).

NcRNAs are documented to be the main regulators of a number of biological processes, such as transcription, splicing, translation, epigenetic gene expression, cell cycle (8-12), stem cell pluripotency and reprogramming $(12,13)$, embryogenesis (14), and regulation of the immune response (15). They are divided into small ncRNAs ( $<200 \mathrm{nt})$ and long ncRNAs (lncRNAs; >200 nt) (16,17). LncRNAs are classified according to the correlation between their location and the location of the corresponding protein-coding gene, such as sense, antisense, intergenic, intronic and bidirectional lncRNAs $(18,19)$. Aberrant expression of lncRNAs may contribute to the development and progression of various cancers (20-25).

The lncRNA prostate cancer-associated non-coding RNA 1 (PRNCR1), also referred to as PCAT8 and CARLo3, is mapped to $8 \mathrm{q} 24.21$ (26). It has been stated that PRNCR1 is upregulated in PCa and is involved in PCa development by modulating androgen receptor (AR) activity (27). Binding of PRNCR 1 to the acetylated AR and its association with DOT1L recruit a second lncRNA, PCGEM1, to the DOT1L-mediated methylated N-terminus of the AR (27). The interactions of these overexpressed lncRNAs may serve as important regulators in $\mathrm{PCa}$.

To date, certain studies have investigated the impact of PRNCRl polymorphisms on the risk of various cancers, including prostate $(26,28-30)$, gastric $(31,32)$ and colorectal cancer (33). 
PRNCR I variants that were identified as potential risk factors for cancer were selected $(26,28-30,34,35)$. Genetic risk factors for cancer may vary among diverse populations. Consequently, repeating previously reported genetic associations in other populations is necessary to determine the genetic risk in each population. To the best of our knowledge, there has yet been no study investigating the effect of $P R N C R I$ variants on cancer risk in the Iranian population. Therefore, the aim of the present study was to determine whether there is an association between the PRNCR1 rs13252298, rs1456315, rs7841060 and rs7007694 polymorphisms and the risk of PCa in a sample of the Iranian population.

\section{Patients and methods}

Patients. In total, 358 subjects participated in this hospital-based case-control study, including 178 unrelated men with histopathologically confirmed prostate cancer and 180 age-matched unrelated men with benign prostatic hyperplasia (BPH), with no history of any type of cancer, as the control group (36-39). All cases and controls were selected from a university-affiliated referral center (Shahid Labbafinejad Medical Center, Shahid Beheshti University of Medical Sciences, Tehran, Iran). The local Ethics Committee of Zahedan University of Medical Sciences approved the project (IR.ZAUMS.REc.1395.102), and written informed consent was obtained from all the participants. Genomic DNA was extracted by the salting out method and stored at $-20^{\circ} \mathrm{C}$ until use. Peripheral blood samples were collected in tubes containing EDTA and genomic DNA was extracted by the salting out method.

Genotyping. The polymerase chain reaction (PCR)-restriction fragment length polymorphism assay was used for genotyping of the PRNCR1 rs13252298,rs1456315, rs7841060, and rs7007694 polymorphisms. The primer sequences, restriction enzymes and the length of the PCR products are listed in Table I. PCR was performed with the commercially available prime Taq Premix (Genet Bio, Daejeon, Korea) according to the manufacturer's recommended protocol. Into each $0.20-\mathrm{ml}$ PCR reaction tube, $1 \mu \mathrm{l}$ of genomic DNA (100 ng/ml), $1 \mu \mathrm{l}$ of each primer $(10 \mu \mathrm{M}), 7 \mu \mathrm{l}$ of $2 \mathrm{X}$ master mix and $6 \mu \mathrm{l}$ of $\mathrm{ddH}_{2} \mathrm{O}$ were added. Amplification was performed with an initial denaturation at $95^{\circ} \mathrm{C}$ for $30 \mathrm{sec}$, followed by 30 cycles of $30 \mathrm{sec}$ at $95^{\circ} \mathrm{C}, 30 \mathrm{sec}$ at $62^{\circ} \mathrm{C}$ for $\mathrm{rs} 13252298,60^{\circ} \mathrm{C}$ for rs $1456315,56^{\circ} \mathrm{C}$ for rs 7841060 , and $64^{\circ} \mathrm{C}$ for rs $7007694,72^{\circ} \mathrm{C}$ for $30 \mathrm{sec}$, with a final extension step at $72^{\circ} \mathrm{C}$ for $10 \mathrm{~min}$. Subsequently, $10 \mu \mathrm{l}$ of the PCR products were digested with the appropriate restriction enzymes (Table I). The digested products were separated by agarose gel electrophoresis, visualized by a UV transilluminator and photographed (Fig. 1).

Statistical analysis. All data were analyzed using the statistical package SPSS 22.0 software (IBM Corp., Armonk, NY, USA). The continuous and categorical data were analyzed by the independent samples t-test and $\chi^{2}$ test, respectively. The association among polymorphisms and PCa was calculated by computing the odds ratio (OR) and $95 \%$ confidence interval $(95 \% \mathrm{CI})$ from unconditional logistic regression analyses. Haplotype analysis was performed using SNPStats software (40). The level of statistical significance was set at $\mathrm{P}<0.05$.

\section{Results}

Genotypes and allele frequencies of PRNCR1 polymorphisms. The present study included 178 PCa patients with a mean age \pm standard deviation of $61.53 \pm 6.91$ years, and 180 patients with BPH with a mean age of $62.40 \pm 7.64$ years. No significant difference was found between the groups in terms of age $(\mathrm{P}=0.258)$. The genotypes and allele frequencies of PRNCR1 polymorphisms in cases and controls are presented in Table II. As regards the rs13252298 A>G variant, our findings demonstrated that this variant significantly increased the risk of $\mathrm{PCa}$ in the recessive $(\mathrm{OR}=3.49,95 \% \mathrm{CI}$ : 1.79-6.81, $\mathrm{P}=0.0001, \mathrm{GG}$ vs. AA+AG) inheritance model. As regards the rs1456315 A $>$ G polymorphism, the AG genotype as well as the $\mathrm{G}$ allele significantly increased the risk of $\mathrm{PCa}(\mathrm{OR}=5.16$, 95\% CI: 3.16-8.41, $\mathrm{P}<0.0001$ and $\mathrm{OR}=2.20,95 \% \mathrm{CI}: 1.60-3.03$, $\mathrm{P}<0.0001$, respectively). The TG genotype as well as the $\mathrm{G}$ allele of the rs7841060 variant significantly increased the risk of $\mathrm{PCa}(\mathrm{OR}=5.14,95 \% \mathrm{CI}: 3.15-8.37, \mathrm{P}<0.0001$ and $\mathrm{OR}=2.37$, 95\% CI: 1.71-3.26, $\mathrm{P}<0.0001$, respectively). Our findings demonstrated that the rs7007694 $\mathrm{T}>\mathrm{C}$ polymorphism was not significantly associated with the risk of PCa. A haplotype analysis was performed, and the findings indicated that GTGA and GTGG significantly increased the risk of PCa compared with $\mathrm{rs} 1456315 \mathrm{~A} / \mathrm{rs} 7007694 \mathrm{~T} / \mathrm{rs} 7841060 \mathrm{~T} / \mathrm{rs} 13252298 \mathrm{G}$ (ATTG) (Table III).

Association between clinicopathological characteristics and PRNCRI polymorphisms. The associations between clinicopathological characteristics, including age, stage, prostate-specific antigen (PSA) levels, Gleason score, perineural invasion and surgical margin, and PRNCRI polymorphisms are shown in Table IV. The findings did not support an association between $P R N C R 1$ polymorphisms and the clinicopathological characteristics of $\mathrm{PCa}$ patients.

The Hardy-Weinberg equilibrium (HWE) was calculated and the findings revealed that the genotype distribution in controls was not in HWE.

\section{Discussion}

LncRNAs are involved in tumorigenesis through their function as proto-oncogenes (41) or tumor-suppressor genes (42). Androgen receptor, a member of the nuclear receptor family, is a ligand-activated transcription factor (43). It has been suggested that IncRNA PRNCR1 promotes prostate carcinogenesis via activating AR (26). SNPs, a class of genetic variations, are commonly used in the prediction of cancer risk $(38,44,45)$, prognosis (46) and clinical outcome (47). Cumulative evidence indicates that non-coding genes may be involved in gene expression complexity in humans $(48,49)$. Abnormal expression of IncRNAs has been found to be associated with the development of numerous cancers (50-52). Genome-wide association studies suggested significant and consistent associations of multiple genetic polymorphisms on chromosome $8 \mathrm{q} 24$ with PCa susceptibility (53-58). To 
Table I. Primer sequences for detection of PRNCRI by PCR-RFLP.

\begin{tabular}{|c|c|c|c|}
\hline PRNCRI SNPs & PCR primers $\left(5^{\prime} \rightarrow 3^{\prime}\right)$ & Restriction enzyme & Fragment length (bp) \\
\hline rs13252298 A>G & $\begin{array}{l}\text { F: CAGCACTTGCTGTCTTCTCAGATACgAT } \\
\text { R: TACTCCCCAATCTCTGGTCTTACCT }\end{array}$ & EcoRV & $\begin{array}{l}\text { AA: } 196+28 \\
\text { AG:224+196+28 } \\
\text { GG:224 }\end{array}$ \\
\hline rs1456315 G>A & $\begin{array}{l}\text { F: TTGCATTACCTCAACTAAGCCAAG } \\
\text { R: GGATGAAGAACTGAGGTTGCTAATAAGTC }\end{array}$ & $A c c \mathrm{I}$ & $\begin{array}{l}\text { GG: } 213+30 \\
\text { GA: } 243+213+30 \\
\text { AA: } 243\end{array}$ \\
\hline rs7841060 $\mathrm{T}>\mathrm{G}$ & $\begin{array}{l}\text { F: CACCAATCCCAGAGCCATTTTGT } \\
\text { R: CATTTCTCAGGTAGACCATGAACCTCGTA }\end{array}$ & $R s a \mathrm{I}$ & $\begin{array}{l}\text { TT: } 225 \\
\text { TG: } 225+197+28 \\
\text { GG: } 197+28\end{array}$ \\
\hline rs7007694 T>C & $\begin{array}{l}\text { F: GCGAATGCCATTTGTTTGGACG } \\
\text { R: CCTCCAAAGAGAAGAACGGCT }\end{array}$ & BstuI & $\begin{array}{l}\text { TT: } 222 \\
\text { TC: } 222+200+22 \\
\text { CC: } 200+22\end{array}$ \\
\hline
\end{tabular}

PRNCR1, prostate cancer-associated non-coding RNA 1; PCR-RFLP, polymerase chain reaction-restriction fragment length polymorphism; $\mathrm{SNP}$, single-nucleotide polymorphism; F, forward; R, reverse.
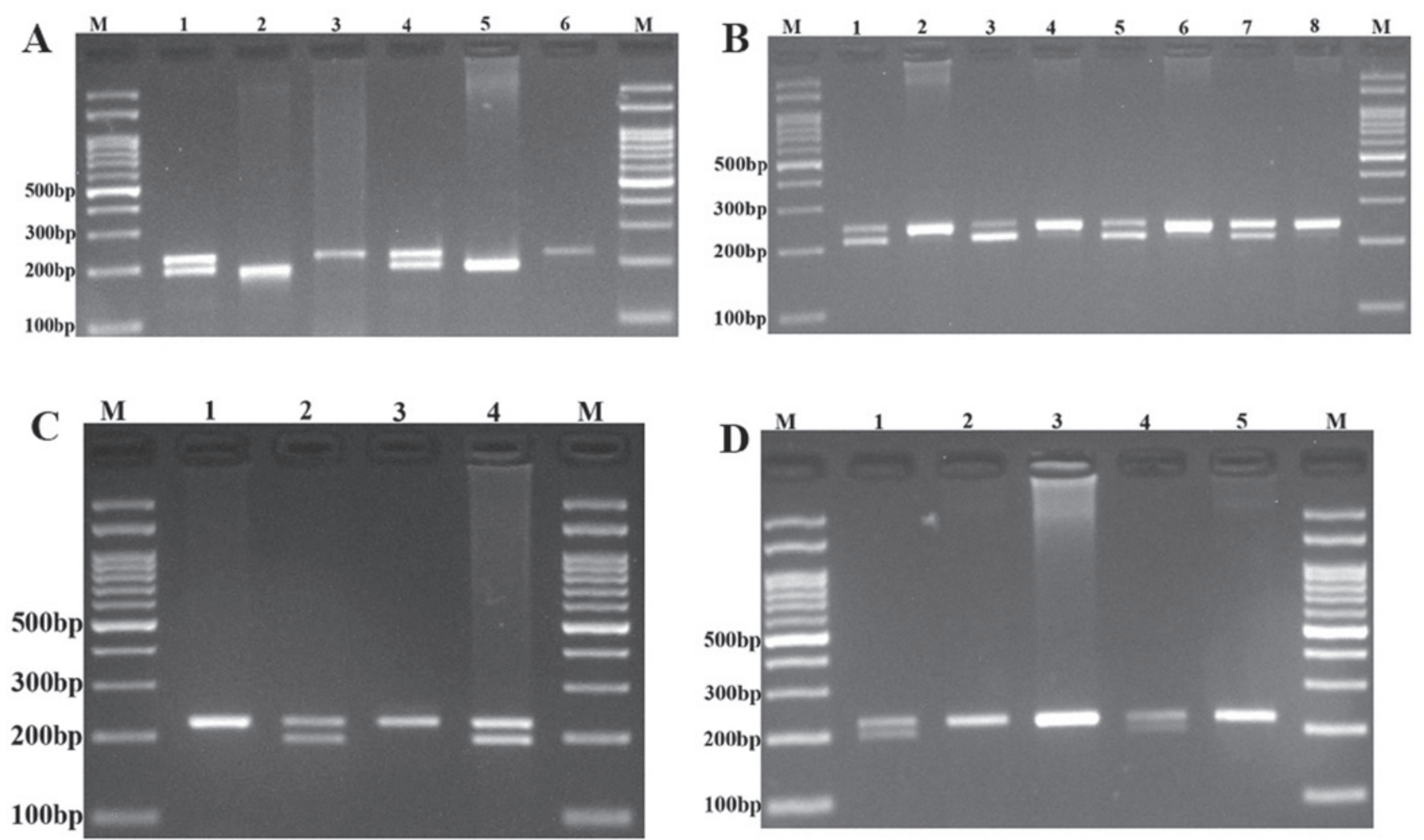

Figure 1. Electrophoresis pattern of the mismatch polymerase chain reaction-restriction fragment length polymorphism method for the detection of $P R N C R I$ polymorphisms (A) rs13252298 A>G and (B) rs1456315 G>A, (C) rs7841060 T>G and (D) rs7007694 T>C. (A) For rs13252298 A>G, M: DNA marker; lanes 1 and 4: AG; lanes 2 and 5: AA; lanes 3 and 6: GG. (B) For rs1456315 G>A, M: DNA marker; lanes 1, 3, 5, and 7: GA; lanes 2, 4, 6, and 8: AA. (C) For rs7841060 T>G, M: DNA marker; lanes 1, and 3: TT; lanes 2, and 4: TG. (D) For rs7007694 T>C, M: DNA marker; lanes 1, and 4: TC; lanes 2, 3, and 5: TC. PRNCR1, prostate cancer-associated non-coding RNA 1.

date, several studies investigated the effect of PRNCRI polymorphisms on the risk of PCa $(26,28-30)$. However, to the best of our knowledge, no study investigating the impact of PRNCRI variants on cancer risk in an Iranian population has been conducted to date. The present study aimed to evaluate the possible association between rs13252298, rs1456315, rs7841060 and rs7007694 polymorphisms of PRNCRI and the risk of PCa in a sample of Iranian population.

Our findings suggested that the PRNCR1 rs13252298, rs1456315 and rs7841060 polymorphisms are significantly associated with increased risk of PCa in our population. 
Table II. The genotype and allele frequencies of PRNCR1 polymorphisms in PCa patients and controls with benign prostatic hyperplasia.

\begin{tabular}{|c|c|c|c|c|}
\hline Polymorphisms & $\mathrm{PCa}, \mathrm{n}(\%)$ & Controls, n (\%) & OR $(95 \% \mathrm{CI})$ & P-value \\
\hline \multicolumn{5}{|l|}{ rs13252298 A>G } \\
\hline \multicolumn{5}{|l|}{ Codominant } \\
\hline AA & 33 (18.6) & $25(14.0)$ & 1.00 & - \\
\hline $\mathrm{AG}$ & $107(60.1)$ & $141(78.8)$ & $0.57(0.32-1.04)$ & 0.078 \\
\hline GG & $38(21.3)$ & $13(7.2)$ & $2.21(0.98-5.01)$ & 0.070 \\
\hline \multicolumn{5}{|l|}{ Dominant } \\
\hline AA & 33 (18.5) & $25(14.0)$ & 1.00 & - \\
\hline $\mathrm{AG}+\mathrm{GG}$ & $145(81.4)$ & $154(86.0)$ & $0.71(0.40-1.26)$ & 0.254 \\
\hline \multicolumn{5}{|l|}{ Recessive } \\
\hline $\mathrm{AA}+\mathrm{AG}$ & 140 (78.7) & $167(92.8)$ & 1.00 & - \\
\hline GG & $38(21.3)$ & $13(7.2)$ & $3.49(1.79-6.81)$ & 0.0001 \\
\hline \multicolumn{5}{|l|}{ Allele } \\
\hline A & $173(48.6)$ & $191(53.4)$ & 1.00 & - \\
\hline G & $183(51.4)$ & 167 (46.6) & $1.21(0.90-1.62)$ & 0.231 \\
\hline \multicolumn{5}{|l|}{$\mathrm{rs} 1456315 \mathrm{~A}>\mathrm{G}$} \\
\hline AA & $30(16.9)$ & $92(51.1)$ & 1.00 & - \\
\hline AG & $148(83.1)$ & 88 (48.9) & $5.16(3.16-8.41)$ & $<0.0001$ \\
\hline GG & $0(0.0)$ & $0(0.0)$ & - & - \\
\hline A & $208(58.4)$ & $272(75.6)$ & 1.00 & - \\
\hline $\mathrm{G}$ & $148(41.6)$ & $88(24.4)$ & $2.20(1.60-3.03)$ & $<0.0001$ \\
\hline \multicolumn{5}{|l|}{$\mathrm{rs} 7841060 \mathrm{~T}>\mathrm{G}$} \\
\hline $\mathrm{TT}$ & $29(16.3)$ & $96(53.3)$ & 1.00 & - \\
\hline TG & 149 (83.7) & $84(46.7)$ & $5.14(3.15-8.37)$ & $<0.0001$ \\
\hline GG & $0(0.0)$ & $0(0.0)$ & - & - \\
\hline $\mathrm{T}$ & $207(58.1)$ & $276(76.6)$ & 1.00 & - \\
\hline $\mathrm{G}$ & $149(41.9)$ & $84(23.4)$ & $2.37(1.71-3.26)$ & $<0.0001$ \\
\hline \multicolumn{5}{|l|}{ rs70007694 T>C } \\
\hline $\mathrm{TT}$ & $150(84.3)$ & 139 (77.2) & 1.00 & - \\
\hline $\mathrm{TC}$ & $28(15.7)$ & $41(22.8)$ & $0.63(0.37-1.08)$ & 0.108 \\
\hline $\mathrm{CC}$ & $0(0.0)$ & $0(0.0)$ & - & - \\
\hline $\mathrm{T}$ & $328(92.1)$ & $319(88.6)$ & 1.00 & - \\
\hline $\mathrm{C}$ & $28(7.9)$ & $41(11.4)$ & $0.66(0.40-1.10)$ & 0.128 \\
\hline
\end{tabular}

PCa, prostate cancer; PRNCR1, prostate cancer-associated non-coding RNA 1; OR, odds ratio; CI, confidence interval.

In a meta-analysis performed by Chu et al (34), the rs1016343 and rs16901946 variants of PRNCR1 were found to significantly increase the risk of cancer; however, their findings did not support a significant association of the rs13252298, rs7007694 and rs1456315 polymorphisms with cancer risk. Another meta-analysis conducted by Lv et al (35) also revealed that two polymorphisms (rs1016343 and rs16901946) of PRNCRl were associated with increased cancer risk.

LncRNAs, a new class of functional ncRNAs, are composed of $>200$ nucleotides and lack protein-coding ability (19). LncRNAs potentially interact with DNA, RNA, as well as protein molecules, to perform diverse regulatory functions, including chromatin remodelling (59), RNA splicing and editing (60), translational inhibition (61), mRNA destruction (62) and epigenetic regulation of gene expression (63-65).
The most important function of lncRNAs is involvement in the transcriptional or post-transcriptional regulation of gene expression (66). Abnormal expression of lncRNAs may facilitate tumor cell proliferation, invasion and metastasis (67-70).

There were certain limitations to the present study, including the number of SNPs that were investigated for the PRNCRl gene, as well as lack of the information regarding survival outcomes and the patients' response to treatment. The reason for the deviation from $\mathrm{HWE}$ in our population was not clear; it may be attributed to genetic drift.

In conclusion, our findings indicated that the PRNCRI rs13252298, rs1456315 and rs7841060 polymorphisms may be a biomarker for PCa development in a sample of the Iranian population. However, further studies should be performed on PCa and other cancers in different ethnicities with larger 
Table III. Haplotype association of PRNCRl polymorphisms with PCa risk.

\begin{tabular}{lccccccc}
\hline rs1456315 & rs7007694 & rs7841060 & rs13252298 & $\begin{array}{c}\text { Controls } \\
\text { (frequency) }\end{array}$ & $\begin{array}{c}\text { PCa } \\
\text { (frequency) }\end{array}$ & OR (95\% CI) & P-value \\
\hline $\mathrm{A}$ & $\mathrm{T}$ & $\mathrm{T}$ & $\mathrm{G}$ & 0.3828 & 0.3367 & 1.00 & - \\
$\mathrm{A}$ & $\mathrm{T}$ & $\mathrm{T}$ & $\mathrm{A}$ & 0.227 & 0.1987 & $1.29(0.60-2.79)$ & 0.52 \\
$\mathrm{G}$ & $\mathrm{T}$ & $\mathrm{G}$ & $\mathrm{A}$ & 0.146 & 0.2293 & $5.09(2.45-10.59)$ & $<0.0001$ \\
$\mathrm{G}$ & $\mathrm{T}$ & $\mathrm{G}$ & $\mathrm{G}$ & 0.0303 & 0.1473 & $18.85(4.93-72.00)$ & $<0.0001$ \\
$\mathrm{~A}$ & $\mathrm{C}$ & $\mathrm{T}$ & $\mathrm{G}$ & 0.0492 & 0.0293 & $0.82(0.16-4.17)$ & 0.81 \\
$\mathrm{~A}$ & $\mathrm{C}$ & $\mathrm{T}$ & $\mathrm{A}$ & 0.0496 & 0.011 & $0.85(0.21-3.37)$ & 0.81 \\
$\mathrm{G}$ & $\mathrm{T}$ & $\mathrm{T}$ & $\mathrm{A}$ & 0.053 & 0.0031 & $0.21(0.02-1.74)$ & 0.15 \\
$\mathrm{~A}$ & $\mathrm{~T}$ & $\mathrm{G}$ & $\mathrm{A}$ & 0.047 & 0.0062 & $0.61(0.15-2.52)$ & 0.49 \\
\hline
\end{tabular}

PRNCR1, prostate cancer-associated non-coding RNA 1; PCa, prostate cancer; OR, odds ratio; CI, confidence interval.

Table IV. Association of PRNCR1 polymorphisms with clinicopathological characteristics of PCa patients.

\begin{tabular}{|c|c|c|c|c|c|c|c|c|c|c|c|c|c|}
\hline \multirow[b]{2}{*}{ Characteristics } & \multicolumn{3}{|c|}{ rs13252298 } & \multirow[b]{2}{*}{ P-value } & \multicolumn{2}{|c|}{ rs1456315 } & \multirow[b]{2}{*}{ P-value } & \multicolumn{2}{|c|}{ rs7841060 } & \multirow[b]{2}{*}{ P-value } & \multicolumn{2}{|c|}{ rs7007694 } & \multirow[b]{2}{*}{ P-value } \\
\hline & AA & $\mathrm{AG}$ & GG & & AA & $\mathrm{AG}$ & & TT & TG & & TT & $\mathrm{TC}$ & \\
\hline $\begin{array}{l}\text { Age at diagnosis } \\
\text { (years), } n\end{array}$ & & & & 0.276 & & & 0.275 & & & 0.373 & & & 0.935 \\
\hline$\leq 65$ & 27 & 72 & 27 & & 24 & 102 & & 23 & 103 & & 106 & 20 & \\
\hline$>65$ & 6 & 35 & 11 & & 6 & 46 & & 6 & 46 & & 44 & 8 & \\
\hline Stage & & & & 0.770 & & & 0.107 & & & 0.144 & & & 0.361 \\
\hline pT1 & 2 & 3 & 3 & & 3 & 5 & & 3 & 5 & & 8 & 0 & \\
\hline pT2a & 7 & 17 & 3 & & 6 & 21 & & 6 & 21 & & 23 & 4 & \\
\hline pT2b & 1 & 7 & 3 & & 0 & 11 & & 0 & 11 & & 10 & 1 & \\
\hline pT2c & 16 & 48 & 19 & & 13 & 70 & & 14 & 69 & & 65 & 18 & \\
\hline pT3a & 3 & 9 & 2 & & 0 & 14 & & 0 & 14 & & 12 & 2 & \\
\hline pT3b & 4 & 23 & 8 & & 8 & 27 & & 6 & 29 & & 32 & 3 & \\
\hline $\begin{array}{l}\text { PSA at diagnosis } \\
(\mathrm{ng} / \mathrm{ml}), \mathrm{n}\end{array}$ & & & & 0.279 & & & 0.571 & & & 0.797 & & & 0.769 \\
\hline$\leq 4$ & 1 & 0 & 1 & & 0 & 2 & & 0 & 2 & & 2 & 0 & \\
\hline $4-10$ & 17 & 49 & 22 & & 13 & 75 & & 14 & 74 & & 73 & 15 & \\
\hline$>10$ & 15 & 57 & 15 & & 17 & 70 & & 15 & 72 & & 74 & 13 & \\
\hline Gleason score, $\mathrm{n}$ & & & & 0.462 & & & 0.150 & & & 0.483 & & & 0.806 \\
\hline$\leq 7$ & 26 & 79 & 32 & & 20 & 117 & & 21 & 116 & & 116 & 21 & \\
\hline$>7$ & 7 & 26 & 6 & & 10 & 30 & & 8 & 32 & & 33 & 7 & \\
\hline Perineural invasion, $\mathrm{n}$ & & & & 0.576 & & & 0.838 & & & 0.680 & & & 0.836 \\
\hline Positive & 22 & 67 & 21 & & 18 & 92 & & 17 & 93 & & 92 & 18 & \\
\hline Negative & 11 & 39 & 17 & & 12 & 55 & & 12 & 55 & & 57 & 10 & \\
\hline Surgical margin, $\mathrm{n}$ & & & & 0.690 & & & 0.839 & & & 0.679 & & & 0.292 \\
\hline Positive & 12 & 44 & 13 & & 11 & 58 & & 10 & 59 & & 61 & 8 & \\
\hline Negative & 21 & 62 & 25 & & 19 & 89 & & 19 & 89 & & 88 & 20 & \\
\hline
\end{tabular}

PRNCR1, prostate cancer-associated non-coding RNA 1; PCa, prostate cancer; PSA, prostate-specific antigen.

sample sizes to fully elucidate the association between PRNCR1 polymorphisms and cancer risk. In addition, the impact of genetic variants on the expression profile of PRNCRI should be considered in future studies.

\section{Acknowledgements}

The authors would like to thank all the subjects who willingly participated in the study. This project was funded by a 
dissertation grant (MSc thesis of HS no. 7832) from Zahedan University of Medical Sciences, Zahedan, Iran.

\section{References}

1. Jemal A, Bray F, Center MM, Ferlay J, Ward E and Forman D: Global cancer statistics. CA Cancer J Clin 61: 69-90, 2011.

2. Hsing AW and Devesa SS: Trends and patterns of prostate cancer: What do they suggest? Epidemiol Rev 23: 3-13, 2001.

3. Huang Q, Whitington T, Gao P, Lindberg JF, Yang Y, Sun J, Väisänen MR, Szulkin R, Annala M, Yan J, et al: A prostate cancer susceptibility allele at 6q22 increases RFX6 expression by modulating HOXB13 chromatin binding. Nat Genet 46 : $126-135,2014$

4. Hazelett DJ, Rhie SK, Gaddis M, Yan C, Lakeland DL, Coetzee SG; Ellipse/GAME-ON consortium; Practical consortium, Henderson BE, Noushmehr $\mathrm{H}$, et al: Comprehensive functional annotation of 77 prostate cancer risk loci. PLoS Genet 10: e1004102, 2014.

5. Spisák S, Lawrenson K, Fu Y, Csabai I, Cottman RT, Seo JH, Haiman C, Han Y, Lenci R, Li Q, et al: CAUSEL: An epigenome- and genome-editing pipeline for establishing function of noncoding GWAS variants. Nat Med 21: 1357-1363, 2015

6. Chen H, Yu H, Wang J, Zhang Z, Gao Z, Chen Z, Lu Y, Liu W, Jiang D, Zheng SL, et al: Systematic enrichment analysis of potentially functional regions for 103 prostate cancer risk-associated loci. Prostate 75: 1264-1276, 2015.

7. ENCODEProject Consortium,Birney E, Stamatoyannopoulos JA, Dutta A, Guigó R, Gingeras TR, Margulies EH, Weng Z, Snyder M, Dermitzakis ET, et al: Identification and analysis of functional elements in $1 \%$ of the human genome by the ENCODE pilot project. Nature 447: 799-816, 2007.

8. Groß S, Immel UD, Klintschar M and Bartel F: Germline genetics of the p53 pathway affect longevity in a gender specific manner. Curr Aging Sci 7: 91-100, 2014.

9. Kino T, Hurt DE, Ichijo T, Nader N and Chrousos GP: Noncoding RNA gas5 is a growth arrest- and starvation-associated repressor of the glucocorticoid receptor. Sci Signal 3: ra8, 2010.

10. Brannan CI, Dees EC, Ingram RS and Tilghman SM: The product of the H19 gene may function as an RNA. Mol Cell Biol 10: 28-36, 1990.

11. Chen B, Yu M, Chang Q, Lu Y, Thakur C, Ma D, Yi Z and Chen F: Mdig de-represses H19 large intergenic non-coding RNA (lincRNA) by down-regulating $\mathrm{H} 3 \mathrm{~K} 9 \mathrm{me} 3$ and heterochromatin. Oncotarget 4: 1427-1437, 2013.

12. Ma L, Bajic VB and Zhang Z: On the classification of long non-coding RNAs. RNA Biol 10: 925-933, 2013

13. Fatica A and Bozzoni I: Long non-coding RNAs: New players in cell differentiation and development. Nat Rev Genet 15: 7-21, 2014.

14. Grote P and Herrmann BG: The long non-coding RNA Fendrr links epigenetic control mechanisms to gene regulatory networks in mammalian embryogenesis. RNA Biol 10: 1579-1585, 2013.

15. Li Z and Rana TM: Decoding the noncoding: Prospective of lncRNA-mediated innate immune regulation. RNA Biol 11: 979-985, 2014

16. Bartel DP: MicroRNAs: Target recognition and regulatory functions. Cell 136: 215-233, 2009.

17. Mattick JS: RNA regulation: A new genetics? Nat Rev Genet 5 316-323, 2004.

18. Derrien T, Johnson R, Bussotti G, Tanzer A, Djebali S, Tilgner H, Guernec G, Martin D, Merkel A, Knowles DG, et al: The GENCODE v7 catalog of human long noncoding RNAs: Analysis of their gene structure, evolution, and expression. Genome Res 22: 1775-1789, 2012.

19. Ponting CP, Oliver PL and Reik W: Evolution and functions of long noncoding RNAs. Cell 136: 629-641, 2009.

20. Lin R, Maeda S, Liu C, Karin M and Edgington TS: A large noncoding RNA is a marker for murine hepatocellular carcinomas and a spectrum of human carcinomas. Oncogene 26 : 851-858, 2007.

21. Pei Z, Du X, Song Y, Fan L, Li F, Gao Y, Wu R, Chen Y, Li W Zhou H, et al: Down-regulation of lncRNA CASC2 promotes cell proliferation and metastasis of bladder cancer by activation of the Wnt/ $\beta$-catenin signaling pathway. Oncotarget 8: 18145-18153, 2017.

22. Li T, Xu C, Cai B, Zhang M, Gao F and Gan J: Expression and clinicopathological significance of the lncRNA HOXA11-AS in colorectal cancer. Oncol Lett 12: 4155-4160, 2016.
23. He A, Chen Z, Mei $\mathrm{H}$ and Liu Y: Decreased expression of LncRNA MIR31HG in human bladder cancer. Cancer Biomark 17: 231-236, 2016

24. Pibouin L, Villaudy J, Ferbus D, Muleris M, Prospéri MT, Remvikos $\mathrm{Y}$ and Goubin G: Cloning of the mRNA of overexpression in colon carcinoma-1: A sequence overexpressed in a subset of colon carcinomas. Cancer Genet Cytogenet 133: 55-60, 2002

25. Calin GA, Liu CG, Ferracin M, Hyslop T, Spizzo R, Sevignani C, Fabbri M, Cimmino A, Lee EJ, Wojcik SE, et al: Ultraconserved regions encoding ncRNAs are altered in human leukemias and carcinomas. Cancer Cell 12: 215-229, 2007.

26. Chung S, NakagawaH,Uemura M,Piao L, Ashikawa K,HosonoN, Takata R, Akamatsu S, Kawaguchi T, Morizono T, et al: Association of a novel long non-coding RNA in 8q24 with prostate cancer susceptibility. Cancer Sci 102: 245-252, 2011.

27. Yang L, Lin C, Jin C, Yang JC, Tanasa B, Li W, Merkurjev D, Ohgi KA, Meng D, Zhang J, et al: IncRNA-dependent mechanisms of androgen-receptor-regulated gene activation programs. Nature 500: 598-602, 2013

28. Hui J, Xu Y, Yang K, Liu M, Wei D, Wei D, Zhang Y, Shi XH, Yang F, Wang N, et al: Study of genetic variants of $8 \mathrm{q} 21$ and $8 \mathrm{q} 24$ associated with prostate cancer in Jing-Jin residents in northern China. Clin Lab 60: 645-652, 2014.

29. Zheng SL, Hsing AW, Sun J, Chu LW, Yu K, Li G, Gao Z, Kim ST, Isaacs WB, Shen MC, et al: Association of 17 prostate cancer susceptibility loci with prostate cancer risk in Chinese men. Prostate 70: 425-432, 2010

30. Salinas CA, Kwon E, Carlson CS, Koopmeiners JS, Feng Z, Karyadi DM, Ostrander EA and Stanford JL: Multiple independent genetic variants in the 8q24 region are associated with prostate cancer risk. Cancer Epidemiol Biomarkers Prev 17: 1203-1213, 2008

31. Li L, Jia F, Bai P, Liang Y, Sun R, Yuan F, Zhang L and Gao L: Association between polymorphisms in long non-coding RNA PRNCR1 in 8q24 and risk of gastric cancer. Tumour Biol 37: 299-303, 2016

32. He BS, Sun HL, Xu T, Pan YQ, Lin K, Gao TY, Zhang ZY and Wang SK: Association of genetic polymorphisms in the LncRNAs with gastric cancer risk in a Chinese population. J Cancer 8: 531-536, 2017.

33. Li L, Sun R, Liang Y, Pan X, Li Z, Bai P, Zeng X, Zhang D, Zhang $\mathrm{L}$ and Gao L: Association between polymorphisms in long non-coding RNA PRNCR1 in 8q24 and risk of colorectal cancer. J Exp Clin Cancer Res 32: 104, 2013.

34. Chu H, Chen Y, Yuan Q, Hua Q, Zhang X, Wang M, Tong N, Zhang W, Chen J and Zhang Z: The HOTAIR, PRNCR1 and POLR2E polymorphisms are associated with cancer risk: A meta-analysis. Oncotarget 8: 43271-43283, 2017.

35. Lv Z, Xu Q and Yuan Y: A systematic review and meta-analysis of the association between long non-coding RNA polymorphisms and cancer risk. Mutat Res 771: 1-14, 2017.

36. Hashemi M, Shahkar G, Simforoosh N, Basiri A, Ziaee SA Narouie B and Taheri M: Association of polymorphisms in PRKCI gene and risk of prostate cancer in a sample of Iranian Population. Cell Mol Biol (Noisy-le-grand) 61: 16-21, 2015.

37. Hashemi M, Moradi N, Ziaee SA, Narouie B, Soltani MH, Rezaei M, Shahkar G and Taheri M: Association between single nucleotide polymorphism in miR-499, miR-196a2, miR-146a and miR-149 and prostate cancer risk in a sample of Iranian population. J Adv Res 7: 491-498, 2016.

38. Hashemi M, Danesh H, Bizhani F, Narouie B, Sotoudeh M, Nouralizadeh A, Sharifiaghdas F, Bahari G and Taheri M: Pri-miR-34b/c rs4938723 polymorphism increased the risk of prostate cancer. Cancer Biomark 18: 155-159, 2017.

39. Hashemi M, Bahari G, Sattarifard H and Narouie B: Evaluation of a 3-base pair indel polymorphism within pre-microRNA-3131 in patients with prostate cancer using mismatch polymerase chain reaction-restriction fragment length polymorphism. Mol Clin Oncol 7: 696-700, 2017.

40. Solé X, Guinó E, Valls J, Iniesta R and Moreno V: SNPStats: A web tool for the analysis of association studies. Bioinformatics 22 : 1928-1929, 2006

41. Li L, Feng T, Lian Y, Zhang G, Garen A and Song X: Role of human noncoding RNAs in the control of tumorigenesis. Proc Natl Acad Sci USA 106: 12956-12961, 2009.

42. Zhang X, Rice K, Wang Y, Chen W, Zhong Y, Nakayama Y, Zhou Y and Klibanski A: Maternally expressed gene 3 (MEG3) noncoding ribonucleic acid: Isoform structure, expression, and functions. Endocrinology 151: 939-947, 2010 
43. Heemers HV and Tindall DJ: Androgen receptor (AR) coregulators: A diversity of functions converging on and regulating the AR transcriptional complex. Endocr Rev 28: 778-808, 2007.

44. Bahari G, Hashemi M, Naderi M and Taheri M: IKZF1 gene polymorphisms increased the risk of childhood acute lymphoblastic leukemia in an Iranian population. Tumour Biol 37: 9579-9586, 2016.

45. Hashemi M, Amininia S, Ebrahimi M, Simforoosh N, Basiri A, Ziaee SAM, Narouie B, Sotoudeh M, Mollakouchekian MJ, Rezghi Maleki E, et al: Association between polymorphisms in TP53 and MDM2 genes and susceptibility to prostate cancer. Oncol Lett 13: 2483-2489, 2017

46. Bao BY, Lin VC, Yu CC, Yin HL, Chang TY, Lu TL, Lee HZ, Pao JB, Huang CY, Huang SP, et al: Genetic variants in ultraconserved regions associate with prostate cancer recurrence and survival. Sci Rep 6: 22124, 2016.

47. Murali A, Varghese BT, Kumar RR and Kannan S: Combination of genetic variants in cyclin D1 and retinoblastoma genes predict clinical outcome in oral cancer patients. Tumour Biol 37: 3609-3617, 2016

48. Kapranov P, Willingham AT and Gingeras TR: Genome-wide transcription and the implications for genomic organization. Nat Rev Genet 8: 413-423, 2007.

49. Kapranov P, Cheng J, Dike S, Nix DA, Duttagupta R, Willingham AT, Stadler PF, Hertel J, Hackermüller J, Hofacker IL, et al: RNA maps reveal new RNA classes and a possible function for pervasive transcription. Science 316 : 1484-1488, 2007

50. Wu SW, Hao YP, Qiu JH, Zhang DB, Yu CG and Li WH: High expression of long non-coding RNA CCAT2 indicates poor prognosis of gastric cancer and promotes cell proliferation and invasion. Minerva Med 108: 317-323, 2017.

51. Guo J, Ma J, Zhao G, Li G, Fu Y, Luo Y and Gui R: Long noncoding RNA LINC0086 functions as a tumor suppressor in nasopharyngeal carcinoma by targeting miR-214. Oncol Res 25: 1189-1197, 2017.

52. Liu JN and Shangguan YM: Long non-coding RNA CARLo-5 upregulation associates with poor prognosis in patients suffering gastric cancer. Eur Rev Med Pharmacol Sci 21: 530-534, 2017.

53. Yeager M, Chatterjee N,Ciampa J, Jacobs KB, Gonzalez-Bosquet J, Hayes RB, Kraft P, Wacholder S, Orr N, Berndt S, et al: Identification of a new prostate cancer susceptibility locus on chromosome 8q24. Nat Genet 41: 1055-1057, 2009.

54. Amundadottir LT, Sulem P, Gudmundsson J, Helgason A, Baker A, Agnarsson BA, Sigurdsson A, Benediktsdottir KR, Cazier JB, Sainz J, et al: A common variant associated with prostate cancer in European and African populations. Nat Genet 38: $652-658,2006$

55. Gudmundsson J, Sulem P, Manolescu A, Amundadottir LT, Gudbjartsson D, Helgason A, Rafnar T, Bergthorsson JT, Agnarsson BA, Baker A, et al: Genome-wide association study identifies a second prostate cancer susceptibility variant at $8 \mathrm{q} 24$. Nat Genet 39: 631-637, 2007.
56. Haiman CA, Patterson N, Freedman ML, Myers SR, Pike MC, Waliszewska A, Neubauer J, Tandon A, Schirmer C, McDonald GJ, et al: Multiple regions within 8q24 independently affect risk for prostate cancer. Nat Genet 39: 638-644, 2007.

57. Eeles RA, Kote-Jarai Z, Giles GG, Olama AA, Guy M, Jugurnauth SK, Mulholland S, Leongamornlert DA, Edwards SM, Morrison J, et al: Multiple newly identified loci associated with prostate cancer susceptibility. Nat Genet 40 : 316-321, 2008

58. Al Olama AA, Kote-Jarai Z, Giles GG, Guy M, Morrison J, Severi G, Leongamornlert DA, Tymrakiewicz M, Jhavar S, Saunders E, et al: Multiple loci on 8q24 associated with prostate cancer susceptibility. Nat Genet 41: 1058-1060, 2009.

59. Keller $\mathrm{C}$ and Bühler M: Chromatin-associated ncRNA activities. Chromosome Res 21: 627-641, 2013.

60. Luco RF and Misteli T: More than a splicing code: Integrating the role of RNA, chromatin and non-coding RNA in alternative splicing regulation. Curr Opin Genet Dev 21: 366-372, 2011.

61. Pircher A, Gebetsberger J and Polacek N: Ribosome-associated ncRNAs: An emerging class of translation regulators. RNA Biol 11: 1335-1339, 2014.

62. Hannon GJ: RNA interference. Nature 418: 244-251, 2002.

63. Lee JT: Epigenetic regulation by long noncoding RNAs. Science 338: 1435-1439, 2012.

64. Khalil AM, Guttman M, Huarte M, Garber M, Raj A, Rivea Morales D, Thomas K, Presser A, Bernstein BE, van Oudenaarden A, et al: Many human large intergenic noncoding RNAs associate with chromatin-modifying complexes and affect gene expression. Proc Natl Acad Sci USA 106: 11667-11672, 2009.

65. Mercer TR, Dinger ME, Sunkin SM, Mehler MF and Mattick JS: Specific expression of long noncoding RNAs in the mouse brain. Proc Natl Acad Sci USA 105: 716-721, 2008.

66. Geisler S and Coller J: RNA in unexpected places: Long non-coding RNA functions in diverse cellular contexts. Nat Rev Mol Cell Biol 14: 699-712, 2013.

67. Spizzo R, Almeida MI, Colombatti A and Calin GA: Long non-coding RNAs and cancer: A new frontier of translational research? Oncogene 31: 4577-4587, 2012.

68. Tsai MC, Spitale RC and Chang HY: Long intergenic noncoding RNAs: New links in cancer progression. Cancer Res 71: 3-7, 2011.

69. Heemers H, Maes B, Foufelle F, Heyns W, Verhoeven G and Swinnen JV: Androgens stimulate lipogenic gene expression in prostate cancer cells by activation of the sterol regulatory element-binding protein cleavage activating protein/sterol regulatory element-binding protein pathway. Mol Endocrinol 15: 1817-1828, 2001.

70. Yang L, Qiu M, Xu Y, Wang J, Zheng Y, Li M, Xu L and Yin R: Upregulation of long non-coding RNA PRNCR1 in colorectal cancer promotes cell proliferation and cell cycle progression. Oncol Rep 35: 318-324, 2016. 